\title{
INDUCTION OF C-MYC G-QUADRUPLEX DNA AND CYTOTOXICITY OF A CALIX[4]ARENE-CONTAINING BINUCLEAR RUTHENIUM(II) COMPLEX
}

\author{
YA-XUAN MI ${ }^{a}$, SHUANG WANG ${ }^{a}$, SHUANG-MEI YAN ${ }^{a}, Y_{U E} C U I^{a}$, MING-HE WANG ${ }^{a}, Z E-B A O Z^{2} H E N G^{b^{*}}$ \\ AND XIAO-LONG ZHAO ${ }^{a^{*}}$
}

${ }^{a}$ College of Chemistry \& Environmental Science, Key Laboratory of Chemical biology of Hebei Province, Hebei University, Baoding 071002, P.R. China.

${ }^{b}$ College of Chemistry and Chemical Engineering, Taishan University, Taian 271021, P.R. China.

\begin{abstract}
Herein, a binuclear ruthenium(II) complex modified by calix[4]arene group has been prepared. The complex as potential inducer and stabilizer of $c-m y c$ Gquadruplex DNA and antitumor reagent were studied. Observations revealed that the complex could bind to $c-m y c$ Pu27 and Pu22 DNA strongly with constants of $1.18 \times 10^{7}(\mathrm{Pu} 27)$ and $4.13 \times 10^{6} \mathrm{M}^{-1}(\mathrm{Pu} 22)$ via groove mode as determined from absorption and luminescence titrations, as well as CD spectra. Results of continuous variation analysis confirmed that the complex interacted with $c$-myc G-quadruplex DNA through a 1:1 binding stoichiometry. As verified by PCR-stop assay, the replication of $c-m y c$ DNA was effectively blocked by the complex with the complete inhibition at the complex concentration of $4.0 \mu \mathrm{M}$ both for Pu27 and Pu22, suggesting that the complex could efficiently induce the formation of $c$-myc G-quadruplex DNA. The appearance of blue TMB solution in the visual experiment also proved that the sequences of Pu27 and Pu22 could fold into G-quadruplex under the induction of the complex. Nevertheless, the complex was found to exhibit weak stabilization ability on $c$-myc G-quadruplex DNA according to FRET assay, which increased the melting point of $c$-myc DNA only $3-3.5^{\circ} \mathrm{C}$. The experiments on Topoisomerase inhibition and cytotoxicity of the complex showed that it acted as an inhibitor of TopoI and exhibited moderate anticancer activity against MCF-7 and Huh-7 tumor cells.
\end{abstract}

Keywords: Ruthenium, c-myc G-quadruplex DNA, Topoisomerase, Cytotoxicity.

\section{INTRODUCTION}

Ruthenium(II) complexes have attracted extensively attentions as potential alternative drugs for cis-platin in metal-based cancer therapy, due to their excellent binding affinity and luminescene-probe behavior for DNA [1-4], high selectivity to tumor cells and relatively low toxicity toward human normal cells [5-8]. Research of the last few decades by Chao et al. revealed that binding of ruthenium(II) complexes with G-quadruplex DNA plays an important role in their inhibition of tumor cell growth [9-11]. It has been found that the Gquadruplex forming guanine-rich sequences widely exist in many regions of chromosomes [12], such as telomeres [13], promoters of oncogenes [14], immunoglobulin switches [15] and the insulin regulatory regions [16]. Particularly, the promoter of oncogene $c-m y c$, which is overexpressed in up to $80 \%$ of solid tumors, but has low expression in normal cells, can also form a Gquadruplex conformation via Hoogesten hydrogen bonds, and is closely related to the proliferation, apoptosis, cell-cycle arrest, invasion and metastasis of tumor cells [17-19].

Therefore, the oncogene $c-m y c$ G-quadruplex DNA as a potential target for antitumor drugs has received increased attention. Up to now, a number of ruthenium(II) complexes have been reported to effectively bind to, induce and stabilize $c-m y c$ G-quadruplex DNA [11,20-27]. Zhang et al. found that complex $\left[\mathrm{Ru}(\text { phen })_{2}(p\right.$-tFMPIP $\left.)\right]\left(\mathrm{ClO}_{4}\right)_{2} \quad\{$-tFMPIP $=2$-(4-(trifluoromethyphenyl)- $1 \mathrm{H}$ imidazo[4,5f][1,10]phenanthroline) $\}$ can stabilize the conformation of $c-m y c$ Gquadruplex DNA in groove binding mode and inhibit the growth of MDA-MB231 cells through apoptosis pathway [22]. Li et al. reported that the aryl alkyne modified complex $\left[\mathrm{Ru}(\mathrm{phen})_{2}(\mathrm{TMSEPIP})\right]\left(\mathrm{ClO}_{4}\right)_{2} \quad\{$ TMSEPIP $=2-(2-$ trimethylsilylethylphenyl)imidazole[4,5f][1,10]phenanthroline) $\}$ can insert into the groove of $c-m y c$ G-quadruplex DNA and can act as a potential luminescent switch-on probe through selectively recognizing and promoting self-assembly of $c$-myc G-quadruplex DNA [21]. Wu et al. demonstrated that a series of arene ruthenium(II) complexes $\left[\left(\eta^{6}-\mathrm{C}_{6} \mathrm{H}_{6}\right) \mathrm{Ru}(p-\mathrm{XPIP}) \mathrm{Cl}\right] \mathrm{Cl}(\mathrm{X}=\mathrm{H} ; \mathrm{F} ; \mathrm{Cl} ; \mathrm{Br}$; and I) $\{\mathrm{PIP}=2$-phenylimidazole[4,5f][1,10]phenanthroline) $\}$ can bind and stabilize $c$ myc G-quadruplex DNA via groove mode and exhibit excellent inhibitory activity against MDA-MB-231 breast cancer cells [20]

However, among the ruthenium(II) complexes reported, limited investigations are focused on the binuclear complexes. Thomas and co-workers

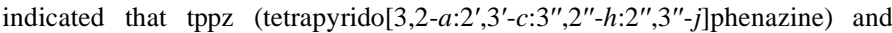

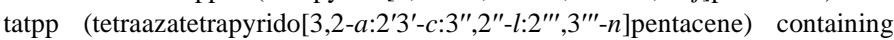
binuclear ruthenium(II) complexes could bind to G-quadruplex DNA with higher affinities than that of duplex DNA molecules [28].
Research results of Zheng et al. about $\left[(\text { bpy })_{2} \mathrm{Ru}(\mathrm{bpibp}) \mathrm{Ru}(\mathrm{bpy})_{2}\right]\left(\mathrm{ClO}_{4}\right)_{4}$ $\left\{\right.$ bpibp $=4,4^{\prime}$-bis $(1,10$-phenanthroline-[5,6- $d$ ] imidazole-2-yl)-biphenyl $\}$ and $\left[(\text { phen })_{2} \mathrm{Ru}(\mathrm{bpibp}) \mathrm{Ru}(\mathrm{phen})_{2}\right]\left(\mathrm{ClO}_{4}\right)_{4}$ evidenced that the binuclear complexes can stabilize the structure of G-quadruplex in the $c-m y c$ promoter and targeting the G-quadruplex loop isomers with inhibition of the proliferation of HepG2 cells [29]. It has been shown that the binuclear complexes generally possess increased size and charge, varied molecular shapes, DNA structural selectivity and great DNA binding affinity, compared to analogous mononuclear complexes, which are advantageous as DNA binders and structural probes [30]. This provokes us to design novel binuclear ruthenium (II) complexes and further understand their interaction with $c-m y c$ G-quadruplex DNA. With this in mind, a calix[4]arenebased binuclear ruthenium(II) complex was prepared in this paper (see Scheme 1), and the affinity of binding to and ability of induction, stabilization of $c$-myc G-quadruplex DNA, Topoisomerase inhibition and anticancer activity of the complex were investigated. The complex was proved to be a promising groove binder and inducer of $c-m y c$ Pu27 and Pu22 DNA, and identified as a Topol inhibitor and potent antitumor agent against MCF-7 and Huh-7 cells.

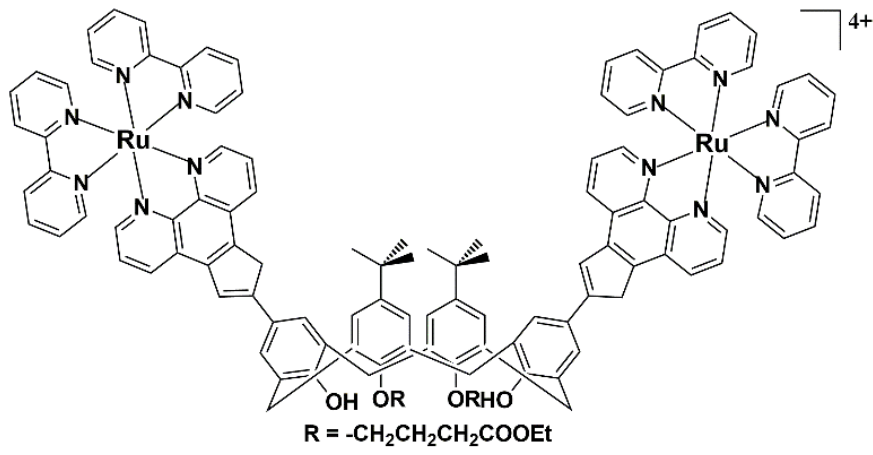

Scheme 1. Molecular structure of ruthenium(II) complex.

\section{EXPERIMENTAL}

\subsection{Materials}

The calix[4]arene-based binuclear ruthenium(II) complex was prepared according to methods described in the literature [31]. The synthetic route and characterization of the complex were given in the supporting information. The molecular structure of the complex is shown in Scheme 1.

*Corresponding author email: longlong_666@sina.com,zhengzebao@163.com 
The other chemicals were obtained from commercial sources and used as received. HTG21 (5'-GGGTTAGGGTTAGGGTTAGGG-3'), c-myc Pu27 (5'-TGGGGAGGGTGGGGAGGGTGGGGAAGG-3'), Pu27rev (5'-ATCGATC GCTTCTCGTCCTTCCCCA-3'), $c$-myc Pu22 (5'-GAGGGTGGGGAGGGTGG GGAAG-3'), Pu22rev (5'-ATCGCTTCTCGTCTTCCCCA-3') and the fluorescent labeled oligonucleotides F27T (5'-FAM-TGGGGAGGGTG GGGAGGGTGGGGAAGG-TAMRA-3', FAM: carboxyfluorescein, TAMRA: 6-carboxytetramethylrhodamine) and F22T (5'-FAM-GAGGGTGGGGAGGG TGGGGAAG-TAMRA-3') were purchased from Sangon Biotech (Shanghai) Co., Ltd. The G-quadruplex conformation was formed by denaturation at $90{ }^{\circ} \mathrm{C}$ for $5 \mathrm{~min}$ followed by renaturation at $4{ }^{\circ} \mathrm{C}$ for $24 \mathrm{~h}[\mathbf{1 2 , 2 1 , 3 2}$. Several buffers of A: $10 \mathrm{mM}$ Tris- $\mathrm{HCl}, \mathrm{pH}=7.4 ; \mathrm{B}: 10 \mathrm{mM}$ Tris- $\mathrm{HCl}, 100 \mathrm{mM} \mathrm{KCl}, \mathrm{pH}=7.4 ; \mathrm{C}$ : $10 \mathrm{mM}$ Tris- $\mathrm{HCl}, 60 \mathrm{mM} \mathrm{KCl}, \mathrm{pH}=7.4$ were applied to the experiments. All aqueous solutions were prepared with Ultrapure MilliQ water (18.2 M $\Omega$ ).

\subsection{DNA binding experiments}

Electronic spectra were measured on a UV-3600 Shimadzu spectrophotometer. Emission spectra were done with a Shimadzu RF-5301PC spectrofluorophotometer. The absorption and luminescence titrations of the ruthenium complex in buffer A were performed with a fixed complex concentration to which increments of $c$-myc G-quadruplex DNA stock solutions were added sequentially. The complex-DNA solutions were incubated for $5 \mathrm{~min}$ before spectra were recorded. The titration processes were repeated until there was no change in the spectra, indicating binding saturation had been achieved.

Circular dichroism (CD) spectra were performed with a Mos-450/SFM300 spectropolarimeter. During the CD titration procedure, aliquots of ruthenium complex solution were added continuously to solutions of $c$-myc G-quadruplex DNA in buffer B. The sample solutions were mixed thoroughly and allowed to equilibrate for $5 \mathrm{~min}$ before data collection. For each sample, the spectrum was scanned at least three times and accumulated over the wavelength range of 230 $320 \mathrm{~nm}$. The titration was repeated until no further change was observed, indicating that the binding saturation had been achieved.

For continuous variation analysis that was conducted with the Shimadzu RF5301PC spectrofluorophotometer, two series of solutions were used: one with varying mole fractions of $[\mathrm{Ru}] /[\mathrm{DNA}]$, and another one with varying concentrations of complexes. The concentration of the Ru-DNA solutions was always $10 \mu \mathrm{M}$. The emission spectra were collected from 500 to $750 \mathrm{~nm}$. The $\Delta I$ values were calculated by subtracting the fluorescence intensity of complex solution without Pu27/Pu22 from the fluorescence intensity of corresponding complex solution with Pu27/Pu22 at $\lambda_{\max }$. This value was plotted versus the complex mole fraction to generate a Job plot.

\subsection{Induction of $c$-myc G-quadruplex DNA by ruthenium complex}

The oligonucleotide Pu27/Pu22 and the corresponding complementary sequence Pu27rev/Pu22rev were used in the Polymerase chain reaction (PCR) stop assay. The PCR-stop assay was performed in $1 \times$ PCR buffer, containing 20 pmol of each oligonucleotide, $0.16 \mathrm{mM}$ dNTPs, $2.5 \mathrm{U}$ Taq polymerase, and different concentrations of ruthenium complex. Reaction mixtures were incubated in a thermocycler with the following cycling conditions: $94{ }^{\circ} \mathrm{C}$ for 3 min, followed by 30 cycles of $94{ }^{\circ} \mathrm{C}$ for $30 \mathrm{~s}, 58^{\circ} \mathrm{C}$ for $30 \mathrm{~s}$, and $72{ }^{\circ} \mathrm{C}$ for $30 \mathrm{~s}$, then $72{ }^{\circ} \mathrm{C}$ for $10 \mathrm{~min}$.

The visual detection of $c-m y c$ G-quadruplex structure was conducted as followes: An equal volume of ruthenium complex solution was added to DNA solutions ( $20 \mathrm{mM}$ DNA, $10 \mathrm{mM}$ Tris-HCl, $100 \mu \mathrm{M}$ EDTA, $\mathrm{pH}=8.00$ ), allowing the DNA strands to form the G-quadruplex structure in $40 \mathrm{~min}$. An equal volume of hemin (in DMSO) was dissolved in the G-quadruplex solutions, which were then kept for $2 \mathrm{~h}$ at room temperature to form the DNAzymes. Subsequently, 180 $\mu \mathrm{L}$ of $296 \mu \mathrm{M}$ TMB $\left(3,3^{\prime}, 5,5^{\prime}\right.$-tetramethylbenzidine)-1.76 $\mathrm{mM} \mathrm{H}_{2} \mathrm{O}_{2}$ solution was added as a substrate for the above $20 \mu \mathrm{L}$ peroxidatic DNAzyme system. The mixture was kept for $1.5 \mathrm{~h}$ at room temperature, and then different colors were observed with the naked eye.

\subsection{Stabilization of $c$-myc G-quadruplex DNA by ruthenium complex}

Fluorescence resonance energy transfer (FRET) melting point assay was carried out on a Roche real time PCR cycler. The fluorescent labeled oligonucleotide F27T/F22T used as the FRET probe was diluted in buffer $\mathrm{C}$ and then annealed by heating to $92{ }^{\circ} \mathrm{C}$ for $5 \mathrm{~min}$, followed by overnight cooling to room temperature. Duplex ct-DNA was a competitive binder to evaluate the selective binding ability of ruthenium complex with G-quadruplex DNA Fluorescence melting curves were monitored by using a total reaction volume of $25 \mu \mathrm{L}$, with labeled oligonucleotide $(1 \mathrm{mM})$ and different concentrations of ruthenium complex in buffer $C$. Fluorescence readings with excitation at $470 \mathrm{~nm}$ and detection at $513 \mathrm{~nm}$ were taken at intervals of $1{ }^{\circ} \mathrm{C}$ from 37 to $95^{\circ} \mathrm{C}$.

\subsection{Topoisomerase inhibition assay}

DNA Topoisomerase I (Topo I) was purchased from New England Biolabs. The reaction mixture $(15 \mu \mathrm{L})$ used in the experiment contained $20 \mathrm{mM}$ Tris- $\mathrm{HCl}$ $50 \mathrm{mM} \mathrm{KCl}, 10 \mathrm{mM} \mathrm{MgCl}, 0.1 \mathrm{mg} / \mathrm{mL}$ BSA, $1 \mathrm{mM}$ DTT (dithiothreitol), 0.25 $\mu \mathrm{g}$ of pBR322 DNA and 2 Unit of Topo I along with varying concentrations of complex. The resultant reaction mixtures were incubated at $37^{\circ} \mathrm{C}$ for $30 \mathrm{~min}$, and stopped by adding $2 \mu \mathrm{L}$ of $6 \times$ loading buffer. The electrophoresis of the samples was passed through $1 \%$ agarose gel (Biowest) in $1 \times$ TBE buffer at 90 $\mathrm{V}$ for $1.5 \mathrm{~h}$. The gel was stained with $1 \mathrm{mg} / \mathrm{mL}$ EB and visualized by UV light, and then photographed on a Bio-Rad gel imaging system.

\subsection{MTT assay}

The cytotoxicity of the ruthenium complex was investigated against A549 (human lung cancer cell), Huh-7 (human hepatocarcinoma cell), MGC-803 (human gastric cancer cell), MCF-7 (human breast cancer cell) and 293T (a normal human cell, human embryonic kidney cell) cell lines on the basis of MTT (3-(4,5-dimethylthiazole)-2,5-diphenyltetrazolium bromide) assay. Cisplatin was used as a reference chemotherapeutic drug. Cells were seeded into a 96-well plate and incubated under $5 \% \mathrm{CO}_{2}$ at $37{ }^{\circ} \mathrm{C}$ for $24 \mathrm{~h}$ in $100 \mu \mathrm{L}$ of cell suspension at a density of $5 \times 10^{3}$ cells per well. The cells were then treated with various concentrations of the tested complex for $48 \mathrm{~h}$. Upon completion of the incubation, stock MTT dye solution $(20 \mu \mathrm{L})$ was added to each well. The microplate was incubated at $37{ }^{\circ} \mathrm{C}$ for another $4 \mathrm{~h}$ in the incubator, and finally sodium dodecyl sulfate (SDS, $100 \mu \mathrm{L}$ ) was added to dissolve the formed formazan crystals. The absorbance of formazan solution was read on a microplate reader at a wavelength of $570 \mathrm{~nm}$.

\section{RESULTS AND DISCUSSION}

\subsection{Binding behavior of ruthenium complex with $c$-myc G-quadruplex} DNA

Absorption spectroscopy is one of the approved methods for examining the interaction of small molecules with biology macromolecules. The interaction of ruthenium complex with $c$-myc G-quadruplex has been firstly investigated by the electronic spectra, as shown in Fig. 1. The absorption spectra of the complex is characterized by a metal-to-ligand charge transfer (MLCT) absorption in the visible region (468 nm), and an intense $\pi \rightarrow \pi^{*}$ intra-ligand (IL) charge transfer in the ultraviolet region $(288 \mathrm{~nm})$. On addition of not only c-myc Pu27 DNA but also $c$-myc Pu22 DNA, obvious hypochromism and red shift were observed. The hypochromism at IL absorption reached as large as 50.6\% with a red shift of 4 $\mathrm{nm}$ at Pu27 binding saturation and $48.4 \%$ accompanied by a bathochromic shift of $4 \mathrm{~nm}$ at Pu22 binding equilibration, although the changes of absorbance of the MLCT bands were slight when [c-myc G-quadruplex DNA] increased. These results gave a hint that the complex exhibited promising affinity to $c$-myc $\mathrm{G}$ quadruplex DNA.

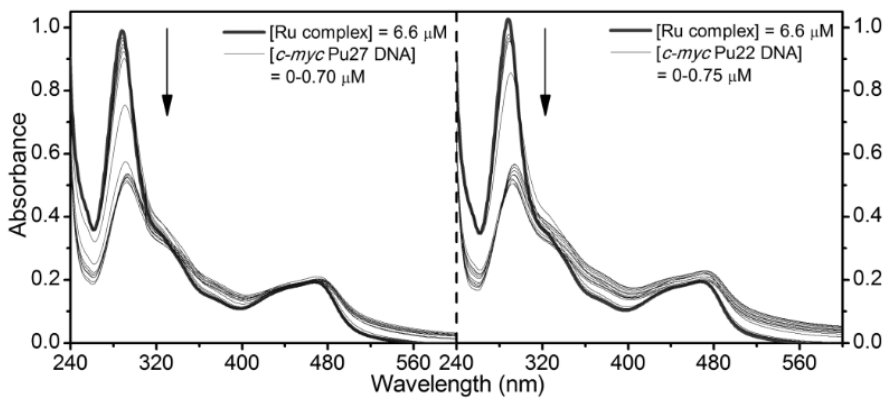

Figure 1. Electronic spectra of ruthenium complex in the absence and presence of $c$-myc G-quadruplex DNA. 
To further clarify the ability of the complex binding to $c$-myc G-quadruplex DNA, a luminescence titration study was conducted. As illustrated in Fig. 2, excitation of the complex at $460 \mathrm{~nm}$ in Tris- $\mathrm{KCl}$ buffer resulted in an intense ${ }^{3} \mathrm{MLCT}\left\{\operatorname{Ru}(\mathrm{d} \pi) \rightarrow \operatorname{ligand}\left(\pi^{*}\right)\right\}$ emission band with $\lambda_{\max }$ around $610 \mathrm{~nm}$. As increasing the concentration of $c-m y c$ Pu27 or Pu22 DNA, the situation of emission for the complex is interesting. Initially, the addition of c-myc DNA causes large reductions in fluorescence intensity, but after reaching a minimum, further additions lead to increasing luminescence intensity until it is higher than that observed before the addition of any $c-m y c$ DNA. The decrease of emission intensity displays that the complex binds to $c-m y c$ DNA through groove mode, which would result in a quenching effect $[29,33]$. On the other hand, the hydrophobic environment inside the DNA leads to the increase of the emission intensity at the later stage of titration. This phenomenon is similar to that observed for $\left[(\text { phen })_{2} \mathrm{Ru}(\mathrm{bpibp}) \mathrm{Ru}(\mathrm{phen})_{2}\right]\left(\mathrm{ClO}_{4}\right)_{4}$ which has been shown to be groove binding to $c$-myc G-quadruplex DNA [29]. The DNA binding affinity of the complex can be evaluated quantitatively by monitoring the increasing of the emission dates in luminescence titration according to Bard-Torp-Murphy equations [34]. As shown in Fig. 2, the Pu27 and Pu22 binding constants were estimated to be $1.18 \times 10^{7}$ and $4.13 \times 10^{6} \mathrm{M}^{-1}$, respectively, which are much larger than $0.43,0.77,53.0,51.0$, and $4.5 \times 10^{5} \mathrm{M}^{-1}$ that reported for $\left[\left(\eta^{6}-\right.\right.$ $\left.\mathrm{C}_{6} \mathrm{H}_{6}\right) \mathrm{Ru}(p$-XPIP)Cl]Cl [20], demonstrating that the complex binds to $c-m y c$ DNA with higher strength.
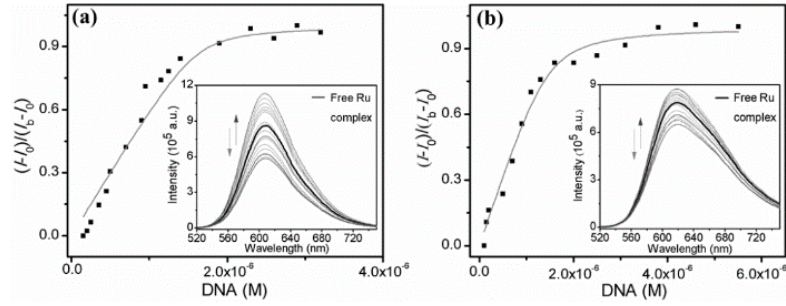

Figure 2. Emission spectra of ruthenium complex in the presence of increasing amounts of $c-m y c$ G-quadruplex DNA, and plot of $\left(I-I_{0}\right) /\left(I_{\mathrm{b}}-I_{0}\right) v s$. [DNA] and the nonlinear fitting. (a) $c-m y c$ Pu27 DNA, $[\mathrm{Ru}]=3.75 \mu \mathrm{M}$, [DNA] $=0-3.2 \mu \mathrm{M}$, (b) $c-m y c$ Pu22 DNA, $[\mathrm{Ru}]=3.75 \mu \mathrm{M},[\mathrm{DNA}]=0-5.5 \mu \mathrm{M}$.

CD spectra can also offer some useful information on the interaction of small molecules with biology macromolecules. After interaction with small molecules, the configuration of DNA will change accordingly and thus reveal different binding modes of the molecules to DNA. The CD spectra of $c-m y c$ G-quadruplex DNA at increasing concentrations of ruthenium complex in Tris- $\mathrm{KCl}$ buffer were illustrated in Fig. 3. The resulting spectra showed that $c-m y c$ G-quadruplex DNA exhibited a parallel structural conformation, which was characterized by a strong positive signal in the range of $250-300 \mathrm{~nm}$ with the maximum at $265 \mathrm{~nm}$, in addition to a weak negative CD signal between 200 and $250 \mathrm{~nm}$ with the maximum at $240 \mathrm{~nm}$ (black line) [23]. After treatment with increasing molar equivalents of complex, the CD signal of $c-m y c$ DNA markedly changed. The strength of the positive signal at $265 \mathrm{~nm}$ decreased by $87.4 \%$ for Pu27 DNA and $71.2 \%$ for Pu22 DNA, and simultaneously an obvious negative induce CD signal at a wavelength of $295 \mathrm{~nm}$ appeared both for Pu27 and Pu22 DNA. These results further confirmed that the complex can interact with $c$-myc DNA tightly through groove mode, which is similar to the Pu27 binding behavior of $\left[\left(\eta^{6}-\mathrm{C}_{6} \mathrm{H}_{6}\right) \mathrm{Ru}(p-\right.$ $\mathrm{ClPIP}) \mathrm{Cl}] \mathrm{Cl}$ reported by $\mathrm{Wu}[20]$, and $\mathrm{Pu} 22$ binding properties of $\left[\mathrm{Ru}(\mathrm{bpy})_{2}(p-\right.$ $\mathrm{BEPIP})]\left(\mathrm{ClO}_{4}\right)_{2} \quad\{p$-BEPIP $\quad=\quad 2$-(4-phenyacetylenephenyl $)-1 \mathrm{H}-$ imidazo[4,5f][1,10]phenanthroline $\}$ reported by Zhang [11].
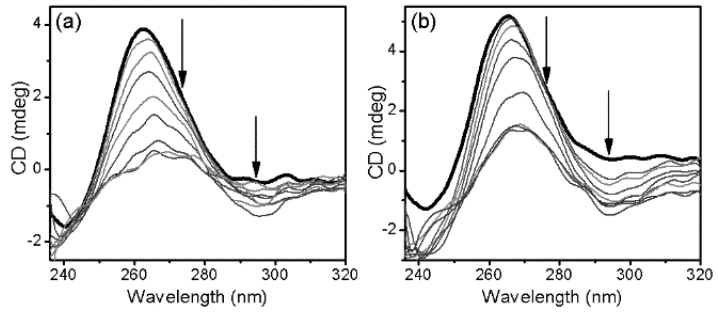

Figure 3. CD spectra of $c-m y c$ quadruplex DNA at increasing concentrations of ruthenium complex in Tris-KCl buffer. (a) $c$-myc Pu27 DNA, [DNA] $=6 \mu \mathrm{M}$, $[\mathrm{Ru}]=0-80 \mu \mathrm{M}$ (b) $c-m y c$ Pu22 DNA, [DNA $]=6 \mu \mathrm{M},[\mathrm{Ru}]=0-80 \mu \mathrm{M}$.
For validating the binding stoichiometry of the ruthenium complex with $c-m y c$ quadruplex DNA, a continuous variation analysis was used. Fixed the total concentration of ruthenium complex and $c$-myc G-quadruplex DNA, the fluorescence intensities of the mixed solutions of complex and $c$-myc DNA with different concentration ratios are different. As given in Fig. 4, the plots of $\Delta I v s$ $X$ showed that the points of intersection of the complex with $c-m y c$ DNA were found to be $X=0.5$ and 0.55 for Pu27 and Pu22, respectively. The data are consistent with the $1: 1$ [quadruplex]/[complex] binding mode, which suggests that a specific Ru-quadruplex interaction occurs with a single guanine tetrad.

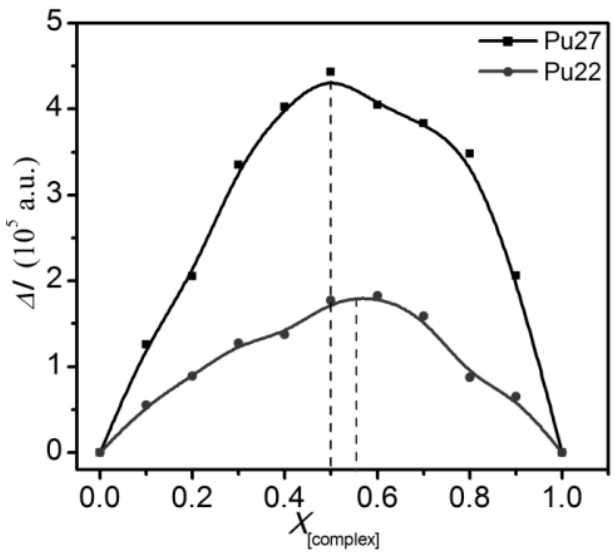

Figure 4. Job plots resulting from the continuous variation analysis for ruthenium complex with c-myc Pu27 and Pu22 quadruplex DNA.

\subsection{Formation of $c$-myc G-quadruplex DNA induced by ruthenium complex}

To evaluate the inhibitory activity of the ruthenium complex against Taq polymerase by inducing the $c$-myc G-quadruplex conformation, a PCR-stop assay was carried out. The sequence of $c$-myc DNA and its corresponding complementary sequence can hybridize to a final double-stranded DNA PCR product when used with Taq DNA polymerase as the catalyst [11]. However, in the presence of some G-quadruplex stabilizers, the template sequence $c$-myc DNA will be induced into a G-quadruplex structure that blocked the hybridization, and in this case, the final PCR product will not be detected. The effect of the complex on the hybridization of $c-m y c$ Pu27 and Pu22 DNA was illustrated in Fig. 5. It is clear that when the complex was added to the solution, the replication of $c-m y c$ oligomer was suppressed. The greater the concentration of the complex is, the smaller is the amount of final product that can be detected. At the complex concentration of $4.0 \mu \mathrm{M}$, the band of the PCR product for both Pu27 and Pu22 DNA completely disappeared, which is attributed to the Gquadruplex structure induced to block the hybridization with a complementary strand. It is noteworthy that the $4.0 \mu \mathrm{M}$ for the complex that displays complete inhibition is much lower than $12 \mu \mathrm{M}, 15 \mu \mathrm{M}$, > $40 \mu \mathrm{M}$ that reported for $\left[(\text { bpy })_{2} \mathrm{Ru}(\right.$ bpibp $\left.) \mathrm{Ru}(\mathrm{bpy})_{2}\right]\left(\mathrm{ClO}_{4}\right)_{2}[29],\left[\mathrm{Ru}(\mathrm{bpy})_{2}\left(\mathrm{dhipH}_{3}\right)\right]\left(\mathrm{ClO}_{4}\right)_{2}\left(\mathrm{dhipH}_{3}=\right.$ 3,4-dihydroxyl-imidazo[4,5-f][1,10]phenanthroline) $\quad[\mathbf{2 3}], \quad\left[\mathrm{Ru}(\mathrm{bpy})_{2}(p-\right.$ TEPIP $)]\left(\mathrm{ClO}_{4}\right)_{2}[\mathbf{1 1}]$ and $\left[\mathrm{Ru}(\mathrm{bpy})_{2}(p\right.$-BEPIP $\left.)\right]\left(\mathrm{ClO}_{4}\right)_{2}[\mathbf{1 1}]$, as listed in Table 1, which evidences that the complex behaves as a promising inducer of $c-m y c \mathrm{G}$ quadruplex DNA. However, in contrast to the efficient induction of $c-m y c \mathrm{G}-$ quadruplex DNA, the complex could not influence human telomeric DNA (HTG21) to fold into G-quadruplex as seen from the results of CD spectra and PCR-stop assay (Fig. 6), which further implies the action selectivity of the complex towards $c$-myc DNA.

\section{Concentration $(\mu \mathrm{M})$}

(a)

\begin{tabular}{lllllllll}
\hline 0 & 0.5 & 1.0 & 1.5 & 2.0 & 2.5 & 3.0 & 3.5 & 4.0 \\
& & & & & & & & \\
\hline
\end{tabular}

(b)

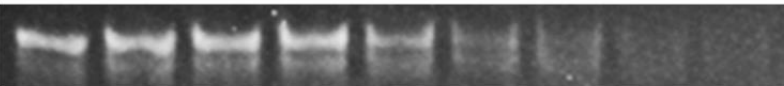

Figure 5. Effect of ruthenium complex on the hybridization of c-myc Pu27 (a) and Pu22 (b) DNA in PCR-stop assay. 
Table 1. The concentration of ruthenium complex for complete inhibition in PCR-stop assay.

\begin{tabular}{|c|c|c|}
\hline Complex & $\begin{array}{l}\text { Concentration of } \\
\text { complete inhibition } \\
\text { (G-quadruplex } \\
\text { DNA) }\end{array}$ & Ref. \\
\hline the present complex & $4 \mu \mathrm{M}$ (Pu27) & $\begin{array}{l}\text { This } \\
\text { work }\end{array}$ \\
\hline$\left[(\mathrm{bpy})_{2} \mathrm{Ru}(\mathrm{bpibp}) \mathrm{Ru}(\mathrm{bpy})_{2}\right]\left(\mathrm{ClO}_{4}\right)_{4}$ & $12 \mu \mathrm{M}(\mathrm{Pu} 27)$ & [29] \\
\hline$\left[(\text { phen })_{2} \mathrm{Ru}(\right.$ bpibp $\left.) \mathrm{Ru}(\text { phen })_{2}\right]\left(\mathrm{ClO}_{4}\right)_{4}$ & $10 \mu \mathrm{M}(\mathrm{Pu} 27)$ & [29] \\
\hline$\left[\mathrm{Ru}(\mathrm{bpy})_{2}\left(\mathrm{dhipH}_{3}\right)\right]\left(\mathrm{ClO}_{4}\right)_{2}$ & $15 \mu \mathrm{M}(\mathrm{Pu} 27)$ & [23] \\
\hline$\left[\mathrm{Ru}(\text { phen })_{2}\left(\mathrm{dhipH}_{3}\right)\right]\left(\mathrm{ClO}_{4}\right)_{2}$ & $12 \mu \mathrm{M}(\mathrm{Pu} 27)$ & {$[23]$} \\
\hline$\left[\left(\eta^{6}-\mathrm{HC}_{6} \mathrm{H}_{5}\right) \mathrm{Ru}(m-\mathrm{MOPIP}) \mathrm{Cl}\right] \mathrm{Cl}$ & $12 \mu \mathrm{M}(\mathrm{Pu} 27)$ & [32] \\
\hline$\left[\left(\eta^{6}-\mathrm{CH}_{3} \mathrm{C}_{6} \mathrm{H}_{5}\right) \mathrm{Ru}(m-\mathrm{MOPIP}) \mathrm{Cl}\right] \mathrm{Cl}$ & $9 \mu \mathrm{M}(\mathrm{Pu} 27)$ & [32] \\
\hline$\left[\mathrm{Ru}(\mathrm{bpy})_{2}(p\right.$-TEPIP $\left.)\right]\left(\mathrm{ClO}_{4}\right)_{2}$ & $>40 \mu \mathrm{M}(\mathrm{Pu} 22)$ & {$[11]$} \\
\hline$\left[\mathrm{Ru}(\mathrm{bpy})_{2}(p-\mathrm{BEPIP})\right]\left(\mathrm{ClO}_{4}\right)_{2}$ & $>40 \mu \mathrm{M}(\mathrm{Pu} 22)$ & [11] \\
\hline$\left[\mathrm{Ru}(\mathrm{ip})_{3}\right]\left(\mathrm{ClO}_{4}\right)_{2} \cdot 2 \mathrm{H}_{2} \mathrm{O}$ & $8 \mu \mathrm{M}(\mathrm{Pu} 23)$ & [35] \\
\hline$\left[\mathrm{Ru}(\mathrm{pip})_{3}\right]\left(\mathrm{ClO}_{4}\right)_{2} \cdot 2 \mathrm{H}_{2} \mathrm{O}$ & $>8 \mu \mathrm{M}(\mathrm{Pu} 23)$ & [35] \\
\hline$\left[\mathrm{Ru}(\mathrm{IP})_{2}(\mathrm{PIP})\right]\left(\mathrm{ClO}_{4}\right)_{2} \cdot 2 \mathrm{H}_{2} \mathrm{O}$ & $15 \mu \mathrm{M}(\mathrm{HTG} 21)$ & [35] \\
\hline$\left[\mathrm{Ru}_{2}(\text { bpy })_{4}(\text { bip-phenol) }]^{4+}\right.$ & $20 \mu \mathrm{M}(\mathrm{HTG} 21)$ & [36] \\
\hline$\Lambda$-[Ru(phen $)_{2}(p$-MOPIP $\left.)\right]^{2+}$ & $15 \mu \mathrm{M}(\mathrm{HTG} 21)$ & [37] \\
\hline$\Delta-\left[\operatorname{Ru}(\text { phen })_{2}(p-\text { MOPIP })\right]^{2+}$ & $20 \mu \mathrm{M}$ (HTG21) & [37] \\
\hline$\left[(\mathrm{bpy})_{2} \mathrm{Ru}\left(\mathrm{ebipcH} \mathrm{H}_{2}\right) \mathrm{Ru}(\mathrm{bpy})_{2}\right]\left(\mathrm{ClO}_{4}\right)_{4}$ & $10 \mu \mathrm{M}$ (HTG22) & [38] \\
\hline$\left[(\text { bpy })_{2} \mathrm{Ru}\left(\mathrm{mbpibH}_{2}\right) \mathrm{Ru}(\mathrm{bpy})_{2}\right]\left(\mathrm{ClO}_{4}\right)_{4}$ & $10 \mu \mathrm{M}(\mathrm{HTG} 22)$ & [38] \\
\hline$\left[(\mathrm{bpy})_{2} \mathrm{Ru}\left(\mathrm{hbpibH} \mathrm{H}_{2}\right) \mathrm{Ru}(\mathrm{bpy})_{2}\right]\left(\mathrm{ClO}_{4}\right)_{4}$ & $12 \mu \mathrm{M}(\mathrm{HTG} 22)$ & [38] \\
\hline
\end{tabular}
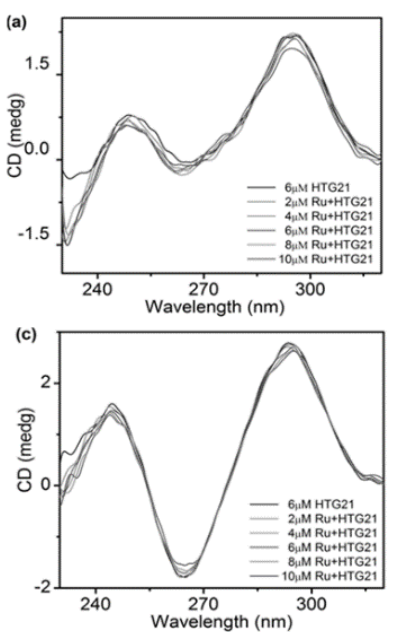
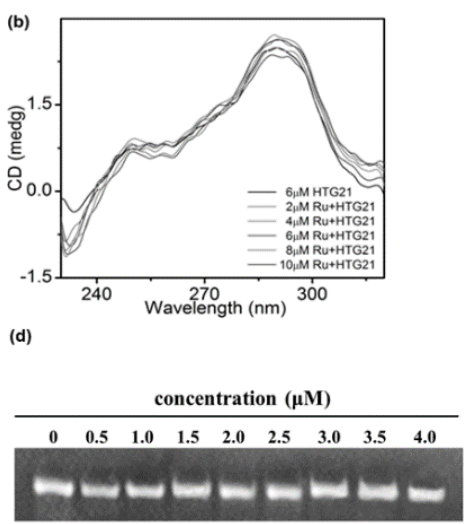

Figure 6. CD spectra of HTG21 DNA at increasing concentrations of ruthenium complex, (a) in Tris-HCl buffer, (b) in Tris-KCl buffer, (c) in Tris$\mathrm{NaCl}$ buffer, (d) effect of ruthenium complex on the hybridization of HTG21 DNA in PCR-stop assay.
To further identify the existence of G-quadruplex with the naked eye, we have adopted an effective and visible method reported by Liu's group [39]. It is well known that G-rich DNA sequences can readily transform to G-quadruplex structures in vitro at physiological concentrations of $\mathrm{Na}^{+}$and $\mathrm{K}^{+}$, and $\mathrm{G}-$ quadruplexes have the ability to bind with hemin to form the peroxidase-like DNAzymes [39]. It is proven that in the presence of DNAzymes, $\mathrm{H}_{2} \mathrm{O}_{2}$-mediated oxidation of TMB can be sharply accelerated and the color change is very sensitive and easy to identify. The design is based on this principle. As shown in Fig. 7, the $\mathrm{H}_{2} \mathrm{O}_{2}$-mediated oxidations of colorless TMB to a blue product was observed with the complex present, as well as control $\mathrm{K}^{+}$. This phenomenon indicates that Pu27-mer and Pu22-mer can fold into G-quadruplex under the induction of complex, and such quadruplex structure is able to bind hemin to form the hemin-G-quadruplex DNAzyme. But for the complex with double strands of ct-DNA, the solution still presents colorless. The reason is obvious, because ct-DNA cannot form G-quadruplex structure.

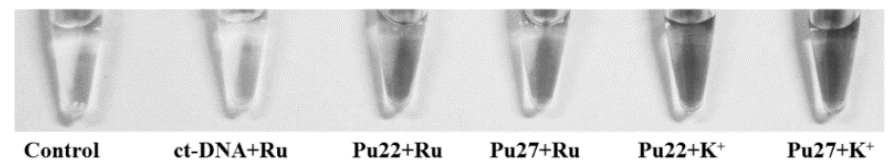

Figure 7. Characterization of the DNAzyme functions of Pu27 and Pu22 DNA in the presence of $500 \mathrm{nM} \mathrm{K}^{+}$and $500 \mathrm{nM}$ ruthenium complex in the TMB- $\mathrm{H}_{2} \mathrm{O}_{2}$ system. Conditions: TMB, $266 \mathrm{mM}$ in Tris-MES bufer (25 mm MES, $\mathrm{pH}=5.10$ ); $\mathrm{H}_{2} \mathrm{O}_{2}, 794 \mathrm{mM}$; DNA, $500 \mathrm{nM}$; hemin, $500 \mathrm{nM}$.

\subsection{Stabilization of $c$-myc G-quadruplex DNA by ruthenium complex}

To investigate the thermodynamic stability of $c$-myc G-quadruplex DNA with the ruthenium complex, a FRET melting point assay was performed to detect the melting temperature $\left(T_{\mathrm{m}}\right)[\mathbf{3 8}, \mathbf{4 0 - 4 3}]$. The F27T and F22T DNA containing fluorophores at both the $5^{\prime}$-end and the 3 '-end was used. The emission of fluorescence was normalized between 0 and 1 , and the $T_{\mathrm{m}}$ was defined as the melting temperature for which the normalized emission is 0.5 . The enhanced melting temperature $\left(\Delta T_{\mathrm{m}}\right)$ was calculated by subtracting the $T_{\mathrm{m}}$ of the free fluorescence-labeled oligonucleotide F27T or F22T from the $T_{\mathrm{m}}$ of the nucleic acid in the presence of the complex, representing the ability of the complex to stabilize the G-quadruplex DNA. The normalized melting curves of F27T and F22T DNA treated the complex were illustrated in Fig. 8. The $T_{\mathrm{m}}$ value of free $\mathrm{F} 27 \mathrm{~T}$ in $\mathrm{K}^{+}$buffer was found to be $72{ }^{\circ} \mathrm{C}$ under our experimental conditions. However, the stabilization effect of the complex on c-myc F27T DNA was proved to be relatively weak, which gave the largest $\Delta T_{\mathrm{m}}$ value of only $3.5^{\circ} \mathrm{C}$ at the concentration of $[\mathrm{Ru}]=0.8 \mu \mathrm{M}$. Similar result appeared for F22T, of which the $T_{\mathrm{m}}$ value was raised maximaly but only $3.0^{\circ} \mathrm{C}$ at the $0.8 \mu \mathrm{M}$ concentration of complex. Moreover, in the presence of increasing amount of double helical ctDNA in the concentration rang of $1-5 \mu \mathrm{M}$, the melting temperatures of F27T and F22T gradually decreased again, as shown in Fig. S3. The observed weak ability of the complex to stabilize $c$-myc quadruplex DNA may be due to the serious steric hindrance for interacting with DNA, which arises from the bulky structure of the complex. This phenomenon is also similar to $\left[\mathrm{Ru}_{2}(\mathrm{bpy})_{4}(\mathrm{bip}-\right.$ phenol $)]\left(\mathrm{ClO}_{4}\right)_{4}\{$ bip-phenol $=2,4$-bis $(1 \mathrm{H}$-imidazo[ $4,5-f][1,10]$ phenanthroline2-yl)phenol\} with the greatest $\Delta T_{\mathrm{m}}$ value of $3{ }^{\circ} \mathrm{C}$ for HTG21 at concentration of $[\mathrm{Ru}]=0.5 \mu \mathrm{M}$. This result would benefit from further investigation.

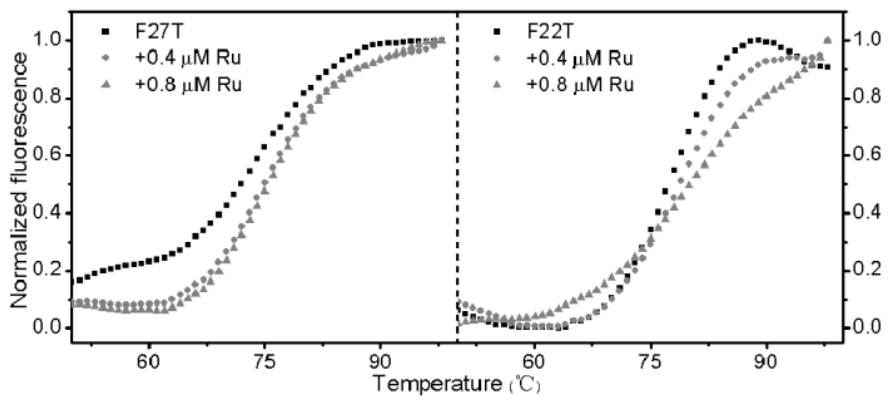

Figure 8. Normalized FRET melting curves of F27T and F22T alone, and with increasing concentrations of ruthenium complex measured by real-time PCR system. 


\subsection{Topoisomerase inhibition}

Topoisomerase enzyme is fundamental part of the cellular processes. It has been reported that in cancerous cells, Topo I enzyme can make transient breaks in single strand of supercoiled pBR322 DNA and covalently linked to DNA to form stable Topo I-DNA complexes. The inhibitors of topo I act on Topo IDNA complexes and finally lead to DNA damage during replication process [4446]. Therefore, topoisomerase enzyme is considered to be a promising drug target in the chemotherapy. The results of Topo I inhibition assay by different concentrations of the ruthenium complex were given in Fig. 9. The supercoiled plasmid DNA can be entirely relaxed by Topo I in the absence of the complex (lane 2). As the concentration of the complexes increased (1-4 $\mu \mathrm{M})$, the amount of the relaxed DNA decreased gradually (lanes 3-6), implying that the complex may block the DNA strand passage event of the enzyme and may serve as an inhibitor of Topo I.

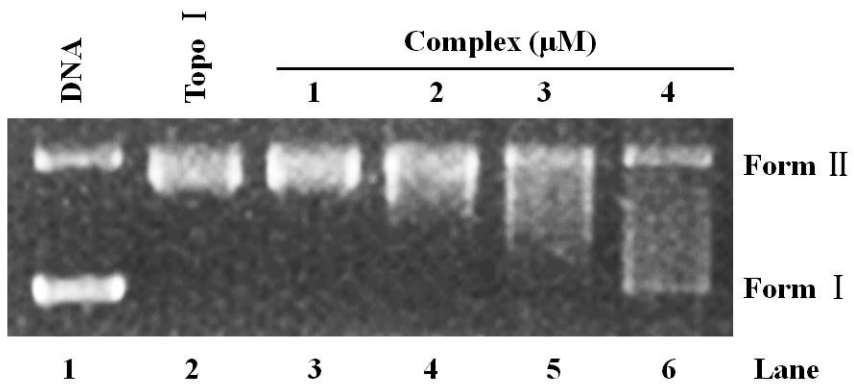

Figure 9. Effect on the activity of DNA Topo I by varying concentrations of ruthenium complex.

\subsection{In vitro cytotoxicity}

We evaluated the in vitro cytotoxic activity of the complex on four selected human cancer cell lines (A549, Huh-7, MGC-803, MCF-7) and one normal cell line (293T) using the MTT assay to determine the potential of the complex as an anticancer agent. Cisplatin was included as a positive control. The above cell lines were incubated with different concentrations of the complex for $48 \mathrm{~h}$, and the $\mathrm{IC}_{50}$ values for the complex against these cell lines are summarized in Table 2. As shown in Table 2, the complex displayed moderate cytotoxic activity against MCF-7 and Huh-7 and simultaneously exhibited less toxic activity toward the normal human cell 293T, while it did not show appreciable inhibition of the cell growth toward A549 and MGC-803 with $\mathrm{IC}_{50}>100 \mu \mathrm{M}$. The previous results of cellular imaging and cytotoxicity experiments of the complex also found that it can rapidly penetrate through the HeLa cells (human cervical carcinoma cell) membrane and had somewhat antiproliferative effect on HeLa cell at the imaging concentration [31]. Therefore, the complex can be a candidate of anticancer agents, although its cytotoxic action is lower than that of cisplatin.

Table 2. The $\mathrm{IC}_{50}$ values of the ruthenium complex toward different cell lines.

\begin{tabular}{|c|c|c|c|c|c|}
\hline \multirow{2}{*}{ Compound } & \multicolumn{5}{|c|}{ IC 5 values $(\boldsymbol{\mu M})$} \\
\cline { 2 - 6 } & $\mathbf{A 5 4 9}$ & Huh-7 & MGC-803 & MCF-7 & 293T \\
\hline $\begin{array}{c}\text { the present } \\
\text { complex }\end{array}$ & $>100$ & $67.08 \pm 5.45$ & $>100$ & $43.46 \pm 4.01$ & $80.79 \pm 5.41$ \\
\hline cisplatin & $18.63 \pm 0.26$ & $18.27 \pm 0.75$ & $13.47 \pm 0.26$ & $12.05 \pm 0.03$ & $20.72 \pm 1.23$ \\
\hline
\end{tabular}

\section{CONCLUSION}

A calix[4]arene-based binuclear ruthenium(II) complex has been successfully achieved. The interaction of the complex with $c$-myc G-quadruplex DNA were studied by photophysical and biophysical means of spectroscopic titrations, CD titration spectra, color reaction studies, Job plot, PCR-stop assay, and FRET assay. The anticancer activity of the complex was evaluated by MTT assay, and the Topoisomerase inhibition was examined as well. The results suggested that the complex could bind to $c$-myc DNA by good affinity, with the Pu27 and Pu22 binding constants as large as $1.18 \times 10^{7}$ and $4.13 \times 10^{6} \mathrm{M}^{-1}$, respectively. It was found to interact with $c$-myc G-quadruplex DNA in groove mode with a $1: 1$ binding ratio, and notably it was identified to be an efficient inducer of $c-m y c$ Gquadruplex DNA although with weak stabilization effect on $c$-myc G-quadruplex DNA.
The complex also displayed TopoI inhibition activity and antiproliferative activity toward MCF-7 and Huh-7 tumor cells, with $\mathrm{IC}_{50}$ values of $(67.08 \pm 5.45)$ $\mu \mathrm{M}$ and $(43.46 \pm 4.01) \mu \mathrm{M}$ for MCF-7 and Huh-7 lower than $(80.79 \pm 5.41) \mu \mathrm{M}$ for $293 \mathrm{~T}$ normal cells. In sum, the complex can be developed as a potential inhibitor in chemotherapy through its interaction with $c$-myc G-quadruplex DNA.

\section{ACKNOWLEDGEMENTS}

The authors thank the National Natural Science Foundation (No. 21401038), Natural Science Foundation of Hebei Province (No. B2016201122), the Science and Technology Development Plan Project of Baoding City (No.14ZF009), the Science and Technology Development Plan Project in Tai'an City (No 2015GX2048), and the Scientific Research Foundation of Taishan University (No. Y-01-2014017)

\section{CONFLICT OF INTEREST}

On behalf of all authors, the corresponding author states that there is no conflict of interest.

\section{REFERENCES}

1. E. Babu, J. Bhuvaneswari, P.M. Mareeswaran, P. Thanasekaran, H.M. Lee, S. Rajagopal, Coordin. Chem. Rev. 380, 519-549, (2019).

2. G. Piraux, L. Bar, M. Abraham, T. Lavergne, H. Jamet, J. Dejeu, L. Marcélis E. Defrancq, B. Elias, Chem. Eur. J. 23, 11872-11880, (2017).

3. J. Rubio-Magnieto, S. Kajouj, F.D. Meo, M. Fossépré, P. Trouillas, P. Norman, M. Linares, C. Moucheron, M. Surin, Chem. Eur. J. 24, $15577-$ 15588, (2018).

4. J. Weynand, A. Diman, M. Abraham, L. Marcélis, H. Jamet, A. Decottignies, J. Dejeu, E. Defrancq, B. Elias, Chem. Eur. J. 24, 1921619227, (2018).

5. A.R. Simović, R. Masnikosa, I. Bratsos, E. Alessio, Coordin. Chem. Rev. 398, 113011-113036, (2019).

6. V. Brabec, J. Kasparkova, Coord. Chem. Rev. 376, 75-94, (2018).

7. M. Pal, U. Nandi, D. Mukherjee, Eur. J. Med. Chem. 150, 419-445, (2018)

8. J.P. Liu, Z. Chen, T.W. Rees, L.B. Ke, L.N. Ji, H. Chao, Coord. Chem. Rev. 363, 17-28, (2018).

9. G.L. Liao, X. Chen, J.H. Wu, C. Qian, Y. Wang, L.N. Ji, H. Chao, Dalton Trans. 44, 15145-15156, (2015).

10. X. Chen, J.H. Wu, Y.W. Lai, R. Zhao, H. Chao, L.N. Ji, Dalton Trans. 42 , 4386-4397, (2013).

11. S.Y. Zhang, Q. Wu, H. Zhang, Q. Wang, X.C. Wang, W.J. Mei, X.H. Wu, W.J. Zheng, J. Inorg. Biochem. 176, 113-122, (2017).

12. H.J. Yu, Y. Zhao, W.J. Mo, Z.F. Hao, L. Yu, Spectrochim. Acta. A: Mol. Biomol. Spectrosc. 132, 84-90, (2014).

13. A.P. Saraswati, N. Relitti, M. Brindisi, S. Gemma, D. Zisterer, S. Butini, G. Campiani, Drug Discov. Today 24, 1370-1388, (2019).

14. R. Catalano, F. Moraca, J. Amato, C. Cristofari, R. Rigo, L.D. Via, R. Rocca, A. Lupia, A. Maruca, G. Costa, B. Catalanotti, A. Artese, B. Pagano, A. Randazzo, C. Sissi, E. Novellino, S. Alcaro, Eur. J. Med. Chem. 182, 111627, (2019).

15. N. Kim, Curr. Med. Chem. 26, 2898-2917, (2019).

16. B. Rajasekhar, C. Kumar, G. Premkumar, M.A. Bin Riyaz, P.T.V. Lakshmi, T. Swu, Struct. Chem. 30, 727-742, (2019).

17. X.N. Wang, X.X. Su, S.Q. Cheng, Z.Y. Sun, Z.S. Huang, T.M. Ou, Expert Opin. Ther. Pat. 29, 353-367, (2019).

18. M.I. Umar, D.Y. Ji, C.Y. Chan, C.K. Kwok, Molecules 24, 2416, (2019).

19. K.B. Wang, M.S.A. Elsayed, G.H. Wu, N.J. Deng, M. Cushman, D.Z. Yang, J. Am. Chem. Soc. 141, 11059-11070, (2019).

20. Q. Wu, K.D. Zheng, S.Y. Liao, Y. Ding, Y.Q. Li, W.J. Mei, Organometallics 35, 317-326, (2016).

21. L. Li, H.M. Liu, X.K. Liu, S.Y. Liao, Y.T. Lan, Q. Wu, X.C. Wang, Q Wang, S.Y. Zhang, W.J. Mei, RSC Adv. 7, 23727-23734, (2017).

22. Z. Zhang, Q. Wu, X.H. Wu, F.Y. Sun, L.M. Chen, J.C. Chen, S.L. Yang, W.J. Mei, Eur. J. Med. Chem. 80, 316-324, (2014).

23. Y. Liu, Y.N. Liu, L.C. Yang, C.W. Cao, Y.H. Zhou, J. Liu, Med. Chem Commun. 5, 1724-1728, (2014).

24. Z. Zhang, X.H. Wu, F.Q. Sun, F. Shan, J.C. Chen, L.M. Chen, Y.S. Zhou, W.J. Mei, Inorg. Chim. Acta 418, 23-29, (2014).

25. Z. Zhang, W.J. Mei, X.H. Wu, X.C. Wang, B.G. Wang, S.D. Chen, J. Coord Chem. 68, 1465-1475, (2015).

26. L. Scaglioni, R. Mondelli, R. Artali, F.R. Sirtori, S. Mazzini, BBA-Gen. Subjects 1860, 1129-1138, (2016). 
27. T. Lemarteleura, D. Gomeza, R. Paterskia, E. Mandineb, P. Maillietb, J. Rioua, Biochem. Bioph. Res. Co. 323, 802-808, (2004).

28. C. Rajput, R. Rutkaite, L. Swanson, I. Haq, J.A. Thomas, Chem. Eur. J. 12, 4611-4619, (2006)

29. C.P. Zheng, Y.N. Liu, Y. Liu, X.Y. Qin, Y.H. Zhou, J. Liu, J. Inorg. Biochem. 156, 122-132, (2016).

30. K. Suntharalingam, A.J.P. White, R. Vilar, Inorg. Chem. 49, 8371-8380, (2010).

31. Q.Y. Huang, Y.F. Han, Z.B. Zheng, Chinese J. Inorg. Chem. 34, 217-229, (2018).

32. Q. Wu, T.F. Chen, Z. Zhang, S.Y. Liao, X.H. Wu, J. Wu, W.J. Mei, Y.H. Chen, W.L. Wu, L.L. Zeng, W.J. Zheng, Dalton Trans. 43, 9216-9225, (2014).

33. A. Ghosh, P. Das, M.R. Gill, P. Kar, M.G. Walker, J.A. Thomas, A. Das, Chem. Eur. J. 17, 2089-2098, (2011).

34. S. Mardanya, S. Karmakar, D. Mondal, S. Baitalik, Inorg. Chem. 55, $3475-$ 3489, (2016)

35. J.N. Zhang, Q.Q. Yu, Q. Li, L.C. Yang, L.M. Chen, Y.H. Zhou, J. Liu, J. Inorg. Biochem. 134, 1-11, (2014).

36. H.Q. Zhao, X.X. Xu, S. Wang, Y.X. Mi, Z.B. Zheng, X.L. Zhao, Transit. Metal Chem. 43, 539-548, (2018)
37. D.D. Sun, Y.N. Liu, D. Liu, R. Zhang, X.C. Yang, J. Liu, Chem. Eur. J. 18, 4285-4295, (2012).

38. L. Xu, X. Chen, J.H. Wu, J.Q. Wang, L.N. Ji, H. Chao, Chem. Eur. J. 21, 4008-4020, (2015).

39. Q. Li, J.N. Zhang, L.C. Yang, Q.Q. Yu, Q.C. Chen, X.Y. Qin, F.L. Le, Q.L. Zhang, J. Liu, J. Inorg. Biochem. 130, 122-129, (2014).

40. S.N. Georgiades, N.H. Abd Karim, K. Suntharalingam, R. Vilar, Angew. Chem. Int. Ed. 49, 4020-4034, (2010).

41. W. Streciwilk, A. Terenzi, X.L. Cheng, L. Hager, Y. Dabiri, P. Prochnow, J.E. Bandow, S. Wölfl, B.K. Keppler, I. Ott, Eur. J. Med. Chem. 156, 148161, (2018).

42. Q. Wu, S.Y. Liao, G.N. Yu, J. Wu, W.J. Mei, J. Inorg. Biochem. 189, 8190, (2018).

43. K. Duskova, S. Sierra, M.S. Arias-Pérez, L. Gude, Bioorg. Med. Chem. 24, 33-41, (2016).

44. R. Gaur, M. Usman, Spectrochim. Acta. A: Mol. Biomol. Spectrosc. 209, 100-108, (2019).

45. G.L. Ma, X.D. Bi, F. Gao, Z. Feng, D.C. Zhao, F.G. Lin, R. Yan, D.D. Liu, P. Liu, J.B. Chen, H.B. Zhang, J. Inorg. Biochem. 185, 1-9, (2018)

46. Y.C. Wang, C. Qian, Z.L. Peng, X.J. Hou, L.L. Wang, H. Chao, L.N. Ji, J. Inorg. Biochem. 130, 15-27, (2014). 